\title{
Ferrum sulphuricum CONTROLLING POWDERY MILDEW ON TOMATO GENOTYPES $^{1}$
}

\author{
MÁRCIA VARGAS TOLEDO ${ }^{2}$, JOSÉ RENATO STANGARLIN ${ }^{3}$, BRUNA BROTI RISSATO ${ }^{4 *}$, ODAIR JOSÉ KUHN ${ }^{3}$, \\ OMARI DANGELO FORLIN DILDEY ${ }^{3}$, CARLOS MOACIR BONATO ${ }^{4}$
}

\begin{abstract}
Powdery mildew is an important disease in tomato, which requires technologies for its control. Homeopathy is a science that has been improved as an alternative method in agriculture. Thus, this study aimed to evaluate the homeopathic medicine Ferrum sulphuricum in 6, 12, 24, 48, 72 and 96CH dynamizations on powdery mildew control. The experiment was conducted from May to June 2013 in a greenhouse, in split-splitplot design, and the results were compared with the controls $30 \%$ ethanol and distilled water. We evaluated the area under disease progress curve (AUDPC), relative chlorophyll index (SPAD), influence on plant growth by volume and mass of roots, and mass of fruits and shoots and even the pathogen sporulation on leaves. For the AUDPC, all the dynamizations reduced the disease. The Santa Clara genotype showed up to $41 \%$ less and Cedro 31\% less disease compared with the control ethanol, in the upper third of the plant. For the SPAD index, there was an increase of up to $322 \%$ in the middle third of the plant treated with $24 \mathrm{CH}$ dynamization. For the growth variables, all the dynamizations increased up to $197 \%$ the volume and weight of roots for Cedro and Santa Clara. The 6, 12, 24, 72 and $96 \mathrm{CH}$ dynamizations reduced the pathogen sporulation on Santa Clara tomato leaves by up to $40 \%$. The data indicate that the medicine Ferrum sulphuricum can control powdery mildew on tomato, increase the growth of plants and that there is a differential response according to the host genotype.
\end{abstract}

Keywords: Homeopathy. Oidium neolycopersici. Alternative control. Resistance induction.

\section{Ferrum sulphuricum NO CONTROLE DE OÍDIO EM GENÓTIPOS DE TOMATEIRO}

RESUMO - O oídio é uma doença importante do tomateiro, o que demanda tecnologias para seu controle. A homeopatia é uma ciência que vem ganhando espaço como uma alternativa fitossanitária na agropecuária. Desta forma, o objetivo deste trabalho foi avaliar o medicamento homeopático Ferrum sulphuricum nas dinamizações $6,12,24,48,72$ e $96 \mathrm{CH}$ para controle de oídio. O experimento foi realizado em casa de vegetação, em delineamento de parcelas sub-sub-divididas e os resultados comparados com controles etanol $30 \%$ e água destilada. O experimento foi conduzido no período de Maio a Junho de 2013. Foram avaliados área abaixo da curva de progresso da doença (AACPD), índice relativo de clorofila (SPAD), influência no crescimento das plantas pelo volume e massa do sistema radicular, massas de frutos e parte aérea e ainda a esporulação do patógeno nas folhas. Para AACPD, todas as dinamizações reduziram a doença. O genótipo Santa Clara apresentou até $41 \%$ menos e Cedro 31\% menos doença comparados com o controle etanol, no terço superior da planta. Para o índice SPAD, houve incremento de até 322\% no terço médio da planta tratada com a dinamização $24 \mathrm{CH}$. Para as variáveis de crescimento, todas as dinamizações incrementaram em até $197 \%$ o volume de raiz e a massa do sistema radicular para ambos genótipos. As dinamizações 6, 12, 24, 72 e $96 \mathrm{CH}$ reduziram o número de esporos em folhas de tomateiro Santa Clara em até $40 \%$. Os dados indicam que o medicamento Ferrum sulphuricum pode controlar o oídio em tomateiro, incrementar o crescimento das plantas e que existe diferença de acordo com o genótipo trabalhado.

Palavras-chave: Homeopatia. Oidium neolycopersici. Controle alternativo. Indução de resistência.

\footnotetext{
${ }^{*}$ Corresponding author

${ }^{1}$ Received for publication in $09 / 18 / 2020$; accepted in $09 / 01 / 2021$

Paper extracted from the doctoral thesis of the first author.

${ }^{2}$ Instituto de Desenvolvimento Rural do Paraná, Marechal Cândido Rondon, PR, Brazil; marciavtoledo@gmail.com - ORCID: 0000-00034234-3725.

${ }^{3}$ Department of Agronomy, Universidade Estadual do Oeste do Paraná, Marechal Cândido Rondon, PR, Brazil; jose.stangarlin@unioeste.br - ORCID: 0000-0001-8601-9439, ojkuhn@gmail.com - ORCID: 0000-0002-6803-4579, omaridildey@hotmail.com - ORCID: 0000-00015092-3573.

${ }^{4}$ Department of Agronomy, Universidade Estadual de Maringá, Maringá, PR, Brazil; brunarissato@hotmail.com - ORCID: 0000-00016197-8254, cmbonato@uem.br - ORCID: 0000-0002-7359-4765.
} 


\section{INTRODUCTION}

Tomato (Solanum lycopersicum L.) (syn.: Lycopersicon esculentum Mill.) is one of the most produced and consumed vegetable worldwide, since the fruits can be industrialized or destined for fresh consumption (DOSSA; FUCHS, 2017). Due to its cultivation throughout the year and in a wide range of ecosystems, tomato can be affected by various diseases, which result in damage and require the use of pesticides (ALVARENGA, 2004).

One of the most common diseases in tomato crops is powdery mildew, caused by Oidium neolycopersici and Oidiopsis haplophylli (Telomorph-Leveilula taurica) (INOUE-NAGATA et al., 2016). In diseased plants, the fungus mycelium grows on the leaf epidermis, on the upper surface $(O$. neolycopersici) or on the lower surface $(O$. haplophylli), showing a white and fine powder appearance in the foliage, in both young and old leaves, resulting in chlorosis and necrosis (INOUENAGATA et al., 2016; SALVUCI; AEGERTER; MIYAO, 2016).

Powdery mildew is not among the most destructive diseases affecting crops; however, producers and researchers have been paying attention to it in recent years, mainly due to the cultivation increase in protected environment, with higher temperature and no inoculum removal by rainfall, which favors the disease. Due to the absence of pathogen-resistant cultivars, the most efficient control measure has been the use of fungicides (INOUE-NAGATA et al., 2016).

With the development of multiple pesticideresistant pathogen strains, it is necessary to focus on the replacement of chemical usage with alternative substances and adopt techniques in plant disease management that allow the most rational and minimum use of pesticides, for a sustainable and economically profitable agriculture. Furthermore, alternative methods for disease management are expected by the public, due to the increasing concern that fungicides may have negative impact on the environment and human health (YANAR; YANAR; GEBOLOGLU, 2011; RISSATO et al., 2016; SATKOVÁ et al., 2017).

The results observed by some authors suggest that the use of homeopathic medicines is a potential approach for use in sustainable agriculture (CARNEIRO; TEIXEIRA, 2018). In this context, homeopathy can contribute to agriculture that is less dependent on pesticides and more sustainable, in addition to being socially just and environmentally friendly.

Toledo, Stangarlin, and Bonato (2015) verified that the homeopathic medicines Sulphur and Ferrum sulphuricum controlled $A$. solani, with up to $49 \%$ reduction in the incidence of the pathogen in tomato plants. Mioranza et al. (2017) used the homeopathic medicine Thuya occidentalis to control
Meloidogyne incognita in tomato and found reduction in the number of second stage juveniles (J2) in the soil. When evaluating the curative effect of the homeopathic medicines Sulphur and Lycopodium clavatum in tomato plants infected with Sclerotinia sclerotiorum, Marques, Rissato, and Schwan-Estrada (2020) verified up to $75 \%$ reduction in the mortality of plants, indicating the potential of homeopathy for controlling this disease.

Despite the increase of research on the use of homeopathy for controlling plant diseases, few studies are known about the differential response of commercial genotypes to this alternative method. Thus, the aim of this work was to evaluate the potential of the homeopathic medicine Ferrum sulphuricum to control powdery mildew and its influence on the growth of two tomato genotypes.

\section{MATERIAL AND METHODS}

\section{Choosing treatments}

The treatments were chosen based on preliminary in vitro results to verify the fungitoxic action of homeopathic medicines on $A$. solani and on previous works by Toledo et al. (2016). Thus, Ferrum sulphuricum was used in the dynamizations $6, \quad 12,24,48,72$ and $96 \mathrm{CH}$ (centesimal Hahnemannian) and, as controls, 30\% ethanol and distilled water.

\section{Preparing treatments}

Ferrum sulphuricum was prepared from ferrous sulfate heptahydrate $\left(\mathrm{FeSO}_{4} \cdot 7 \mathrm{H}_{2} 0\right)$, according to the Brazilian Homeopathic Pharmacopoeia (ANVISA, 2011), by the mechanical grinding process up to $4 \mathrm{CH}$ and then dilution to $1: 100$ (1 part of the medicine for 99 parts $70 \%$ ethanol) and succussion 100 times to obtain 6, 12, 24, 48, 72 and 96CH (centesimal Hahnemannian), dispensed in $30 \%$ ethanol. Distilled water and $30 \%$ ethanol were used as control treatments.

\section{Greenhouse assays}

The experiment was conducted in a split-plot randomized block design; two plots for genotypes (Cedro and Santa Clara) and seven subplots, six dynamizations $(6,12,24,48,72$ and $96 \mathrm{CH})$ and two control treatments (distilled water and $30 \%$ ethanol). For the variables analyzed over time, such as SPAD index and plant growth, the split-plot design was used; the time was in the sub-subplot.

Seedlings of Cedro and Santa Clara tomato genotypes were produced in polyethylene trays containing organic compost until four leaves developed, and then one seedling was transplanted to each pot containing $8 \mathrm{~L}$ organic compost, soil and 
sand $(1: 3: 1, \mathrm{v} / \mathrm{v} / \mathrm{v})$, corrected as recommended for tomato crop (SOUZA; RESENDE, 2003). Plants were kept in a greenhouse at $26{ }^{\circ} \mathrm{C}$ with sprinkler irrigation, conducted with a single stem, and fertilized with $4 \%$ "Supermagro" biofertilizer $(0.1 \%$ nitrogen; $18 \mathrm{mg} \mathrm{L}^{-1}$ phosphorus, and $506 \mathrm{mg} \mathrm{L}^{-1}$ potassium) at 25 days after transplanting (HAMERSCHMIDT et al., 2012).

Homeopathic medicines were diluted with distilled water at $0.1 \%$ according to Bonato et al. (2012) before spraying at 16 days after transplanting, in the dosage of $10 \mathrm{~mL}$ per plant, and later with fourday intervals, totaling three applications.

\section{Assessing disease severity}

After the onset of the powdery mildew symptoms, which occurred under natural conditions at 14 days after transplanting (DAT), disease severity was estimated by the percentage of leaf area injured. The assessment was performed at 14, 17, 20, 23 and 27 DAT in the lower third of the plant, at 14, 17, 20, $23,27,30,34$ and 36 DAT in the middle third, and at 30,34 and 36 DAT in the upper third. For the lower third, we considered the part below the first floral bunch, for the middle third, between the first and second floral bunch, and for the upper third, above the second bunch. With the data, the disease progress curve and the area under disease progress curve (SHANER; FINNEY, 1977) were calculated with the formula: $\mathrm{AUDPC}=\sum[(\mathrm{Y}+\mathrm{Yi}+1) / 2 * \mathrm{I}]$, in which $\mathrm{Yi}$ and $\mathrm{Yi}+1=\%$ disease severity observed in two consecutive evaluations and $\mathrm{I}=$ time interval between two consecutive evaluations.

\section{Relative chlorophyll index (SPAD)}

The SPAD index was evaluated using the chlorophyll meter Minolta (model SPAD -502) at 14, $17,20,23$ and 27 days on the fourth leaf representing the lower third of the plant, at 14, 17, 20, 23, 27, 30, 34 and 36 days on the seventh leaf, in the middle third, and at 30, 34 and 36 days on the ninth leaf, in the upper third. The evaluations were carried out in the morning; there were four readings per fully expanded leaf and we used the average of these readings.

\section{Analysis of growth variables}

Plant height (from the soil surface to the last leaf insertion), number of leaves and stem diameter (in the region of the first leaf insertion) were measured at 14, 17, 20, 23, 27, 30, 34 and 36 days after transplanting.

Fresh (FWS) and dry (DWS) weights of shoot, fresh (FWF) and dry (DWF) weights of fruit, fruit (FA) and flower (FLA) amounts, volume (VR) and dry weight (DWR) of root system were measured on the $36^{\text {th }}$ day after transplant, after the last severity assessment.

Shoot ratio (SR), root ratio (RR) and fruit ratio (FR) were expressed as percentage by the formula: $\mathrm{R}=$ Weight $\mathrm{I} / \mathrm{TDW} \times 100$, in which Weight I $=$ dry weight of shoot or root or fruit, TDW $=$ DWS + DWR + DWF.

\section{Sporulation of Oidium neolycopersici}

After the end of the experiment, the central leaflet above the second floral bunch of the tomato plants of the two cultivars was removed with scissors and then taken to the laboratory for Oidium neolycopersici sporulation assessment. For this, we counted the lesions of the powdery mildew and prepared a suspension by adding $10 \mathrm{~mL}$ of distilled water in the leaf and scraped the fungus colony, followed by counting the number of spores in a Neubauer chamber (BALBI-PEÑA et al., 2006).

\section{Data analysis}

Data were submitted to analysis of variance and the averages were compared by the Scott-Knott test at $5 \%$ error probability with the SISVAR program (FERREIRA, 2011).

\section{RESULTS AND DISCUSSION}

Regarding area under disease progress curve (Figure 1), for the lower third of tomato plants, there was interaction between genotype and dynamization, in which Santa Clara genotype showed lower values than Cedro at $12 \mathrm{CH}$; however, no isolated effect of the dynamizations for each genotype occurred (Figure 1). In the middle third of plants, there was no interaction between the factors, but only for treatments with dynamizations $6,12,24,72$ and $96 \mathrm{CH}$, differing from the control treatments for Santa Clara genotype, with reduction in the AUDPC of powdery mildew from $20.29 \%(24 \mathrm{CH})$ to $33.23 \%$ $(96 \mathrm{CH})$ as compared to $30 \%$ ethanol. For the upper third of plants, all Ferrum sulphuricum dynamizations had effect on the two tomato genotypes. For Santa Clara, this homeopathic medicine provided AUDPC on average of $41.48 \%$ when compared to $30 \%$ ethanol and, for Cedro, $33.10 \%$. There was a difference between the genotype responses, considering distilled water and Ferrum sulphuricum $96 \mathrm{CH}$, in which Santa Clara showed less disease than Cedro, demonstrating a lower susceptibility of this genotype to the pathogen and still suggesting better response of Santa Clara to this homeopathic medicine in the dynamization $96 \mathrm{CH}$. 

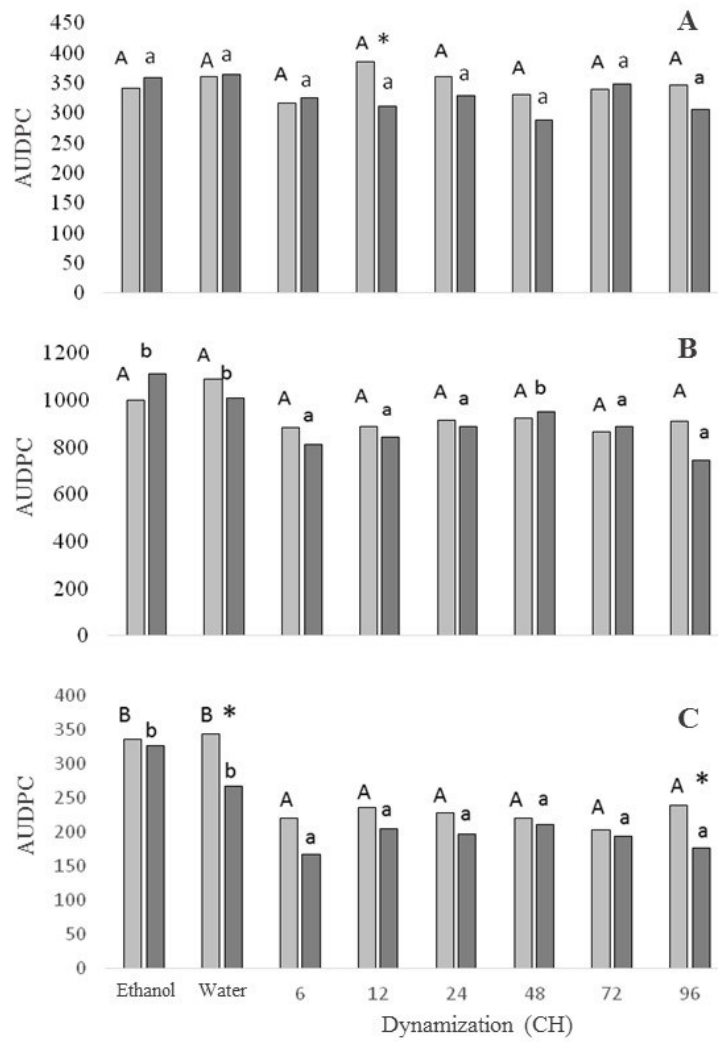

Figure 1. Area under disease progress curve (AUDPC) of Oidium neolycopersici in Cedro $(\square)$ and Santa Clara ( $\square$ ) tomato genotypes treated with Ferrum sulphuricum at 6, 12, 24, 48, 72 and $96 \mathrm{CH}$, compared to distilled water and $30 \%$ ethanol, in the lower third (A), medium third (B) and upper third of the plant (C). Same capital letters for Cedro and lowercase letters for Santa Clara do not differ statistically by the Scott-Knott test at $5 \%$ probability. $(*)$ indicates difference between genotypes. Coefficient of variation $(\%)$ : $(A)=14.62,(B)=17.1$ and $(C)=20.52$.

For the SPAD index (Figure 2), significant difference between treatments occurred at 23 days after transplanting, where Ferrum sulphuricum $6 \mathrm{CH}$ and $12 \mathrm{CH}$ had an increase in chlorophyll content, differing from controls and other dynamizations in the lower third of plants (A). In the last assessment, at 27 days, all dynamizations had this increase when compared to control treatments, ranging from $96.35 \%(12 \mathrm{CH})$ to $123.97 \%(96 \mathrm{CH})$ compared to $30 \%$ ethanol. In the middle third of plants (B), at 34 days, all dynamizations of the Ferrum sulphuricum increased SPAD index compared to the control treatments, which occurred again at 36 days, except for $48 \mathrm{CH}$ and $72 \mathrm{CH}$. In this time, Ferrum sulphuricum increased the SPAD index from $196.97 \% \quad(96 \mathrm{CH}) \quad$ to $322.12 \% \quad(24 \mathrm{CH})$ when compared to $30 \%$ ethanol. In the upper third of plants (C), at 36 days all dynamizations had SPAD index increment compared to the control treatments, ranging from $17.71 \%(12 \mathrm{CH})$ to $37.33 \%(96 \mathrm{CH})$.

SPAD index decreased from 14 to 23 days after transplanting followed by an increase (23 and 27 days) and then a further reduction (30, 34 and 36 days) (Figure 2). The increase in SPAD index reinforces the hypothesis that homeopathy collaborates with the individual self-regulation, or the resumption of homeostasis. In the last assessments (30, 34 and 36 days), there was reduction of the index, which can be related to the environment, since the plants were in pots with limited area.

There was also an interaction between genotypes and dynamizations for SPAD index (Figure 3). All the dynamizations of Ferrum sulphuricum increased the chlorophyll content in the two genotypes, in the lower third of the plants (A). In the second third (B), there was no effect of treatments for Cedro; however, for Santa Clara, Ferrum sulphuricum 6, 12, 24 and 96CH promoted an increase from $16.86 \%(12 \mathrm{CH})$ to $25.96 \%(96 \mathrm{CH})$ compared to $30 \%$ ethanol. In the upper third of plants (C), there was no difference among the dynamizations for each genotype; however, Santa Clara had a higher SPAD index than Cedro in the dynamizations $12 \mathrm{CH}$ and $72 \mathrm{CH}$ and in the distilled water control, indicating a difference in response between genotypes.

Law of similarity, performed by Hahnemann, states that a homeopathic medicine will produce on a healthy being a certain confluence of symptoms, and 
by similarity, it will act with curative action when used to treat the symptoms (PUSTIGLIONE, 2004). Ferrum sulphuricum is recommended for states of anemia and weakness in human and animals, and, by analogy, these symptoms would relate to the reactions of plants to phytopathogens, such as chlorosis.
Homeopathic Ferrum sulphuricum is made of ferrous sulfate heptahydrate $\left(\mathrm{FeSO}_{4} \cdot 7 \mathrm{H}_{2} 0\right)$ and thus has information of iron (Fe) and sulfur (S). When in deficiency, these elements cause chlorosis symptoms in plants. Fe is essential to form chlorophyll, even though it is not part of it, and found mainly in chloroplasts, occurring in proteins of the heme group.
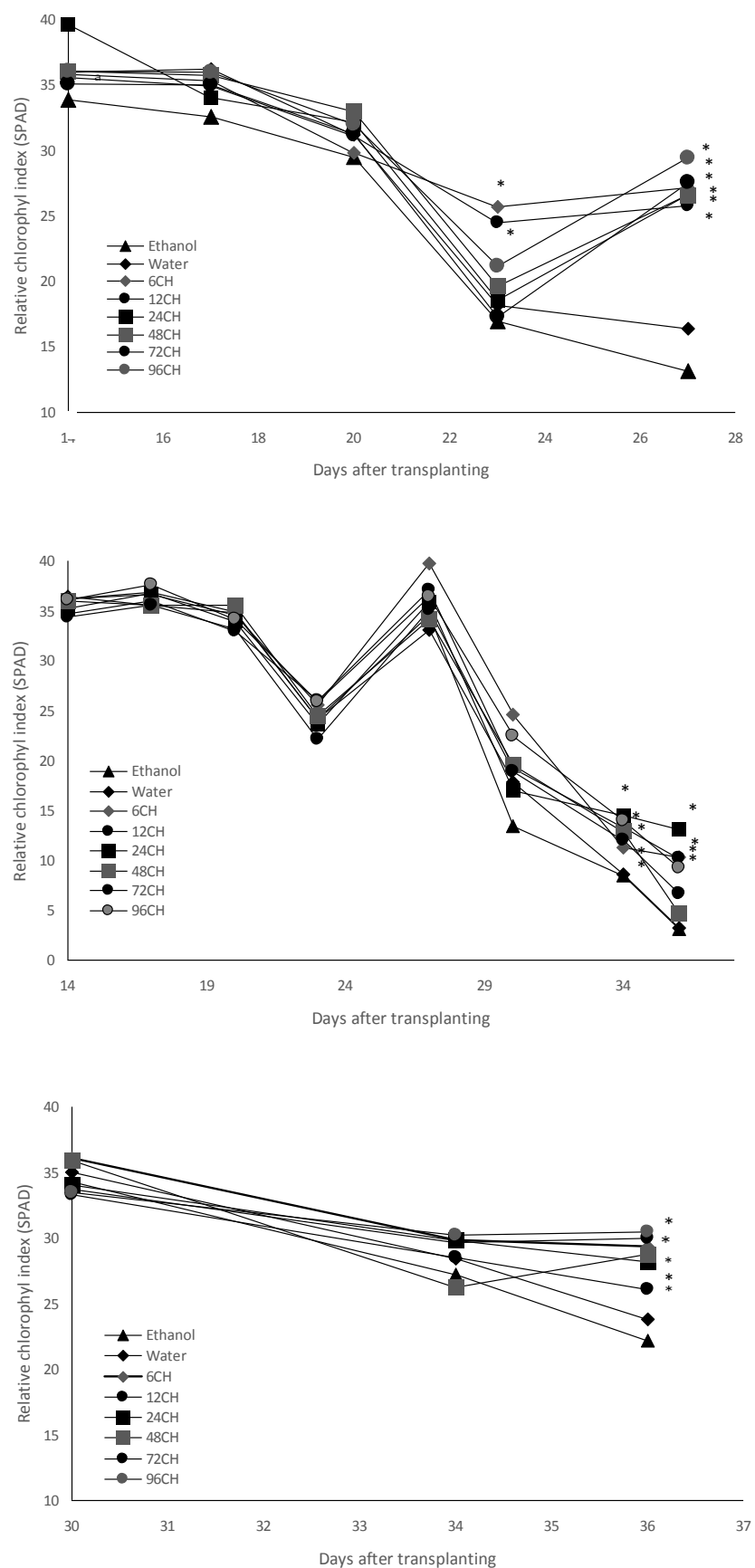

Figure 2. Relative chlorophyll index (SPAD) of tomato plants infected with Oidium neolycopersici and treated with the homeopathic medicine Ferrum sulphuricum in dynamizations 6, 12, 24, 48, 72 and 96CH, compared with $30 \%$ ethanol and distilled water, in the lower third (A), medium third (B) and upper third of the plants $(\mathrm{C}) .(*)$ indicates statistical difference, at the same time, by the Scott-Knott test at 5\% probability level. Coefficient of variation $(\%):(\mathrm{A})=14.7,(\mathrm{~B})=$ 17.37 and $(\mathrm{C})=13.2$.

Rev. Caatinga, Mossoró, v. 35, n. 1, p. 127 - 136, jan. - mar., 2022 


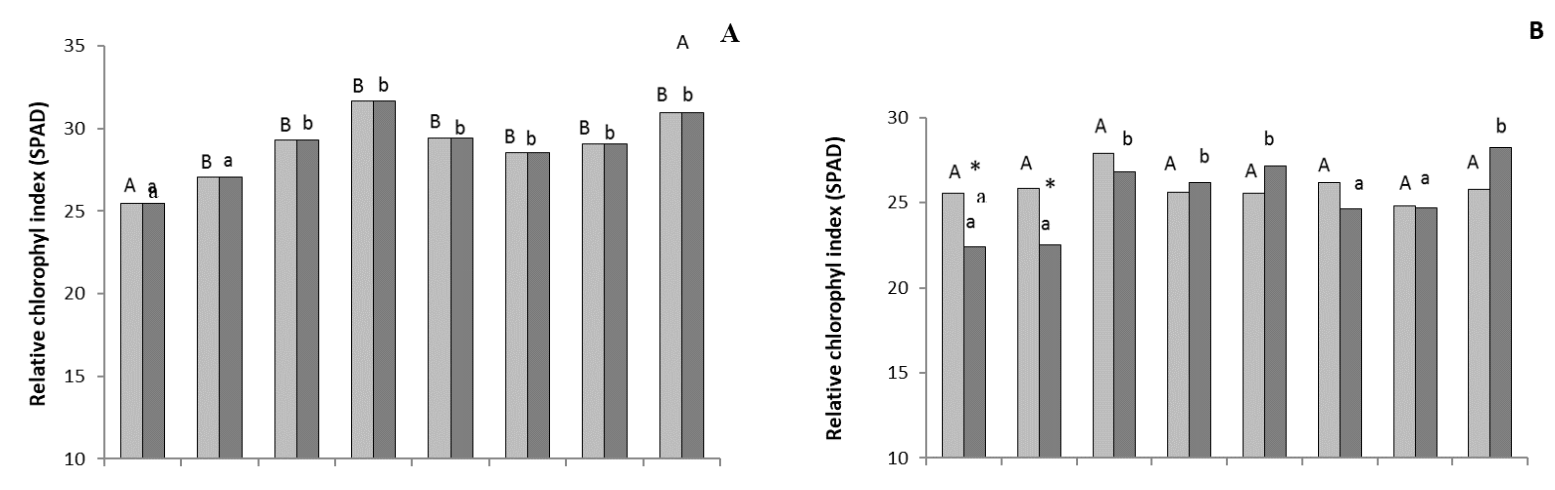

C

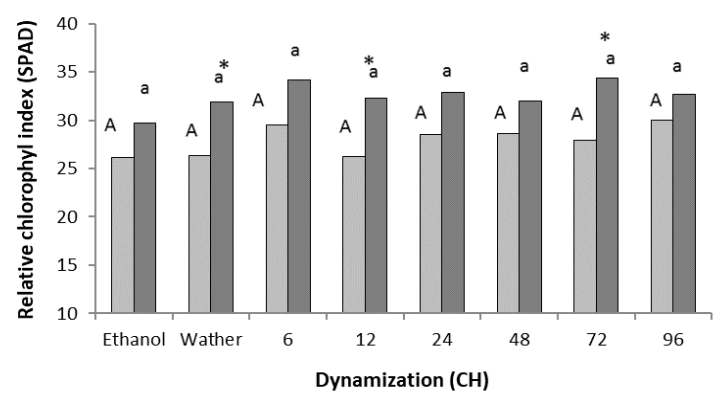

Figure 3. Relative chlorophyll index (SPAD) of Cedro $(\square)$ and Santa Clara $(\square)$ tomato genotypes infected with Oidium neolycopersici and treated with the homeopathic medicine Ferrum sulphuricum in the dynamizations 6, 12, 24, 48, 72 and $96 \mathrm{CH}$, compared to $30 \%$ ethanol and distilled water in the lower third (A), middle third (B) and upper third of plants (C). Same capital letters for Cedro and lowercase letters for Santa Clara do not differ statistically by the Scott-Knott test at $5 \%$ probability level. $(*)$ indicates difference between genotypes. Coefficient of variation $(\%)$ : $(\mathrm{A})=14.7,(\mathrm{~B})=$ 17.37 and $(C)=13.2$.

In addition, it is involved in nitrogen absorption and in several enzymatic pathways linked to processes of oxi-reduction, respiration, photosynthesis, and reduction of nitrate and sulfate. It is part of $\mathrm{Fe}-\mathrm{S}$ proteins, in enzymes such as peroxidase, catalase and ferredoxin, besides being directly involved in the metabolism of nucleic acids, in catalytic and structural functions (MALAVOLTA; VITTI; OLIVEIRA, 1997). Deficiency impairs photochemical capacity and chlorophyll synthesis (TAIZ; ZIEGER, 2013).

Sulfur is part of the molecules of various organic compounds. It acts in the cellular osmotic regulation and ionic balance, participates in the formation of protein and key metabolites of organic metabolism (thiamin and biotin, among others), is an essential component of several amino acids such as cysteine, cystine and methionine, and involved in respiratory activity and redox compounds (TAIZ; ZIEGER, 2013).

Our results indicate that homeopathic Ferrum sulphuricum is able to interfere in the SPAD index; however, further works should be done to elucidate how it acts on chlorophyll metabolism. However, this medicine acts in the general aspect of the plant, and may even indicate a better utilization of soil nutrients, water and light, for example.

For the growth variables, no statistical difference was found for plant height, number of leaves and stem diameter. The plants lasted for 36 days and under artificial conditions, in pots, which was a short time for the total plant development, limiting the genetic potential of the crop and, maybe, the action of the treatments. For the destructive variables, there was difference for fresh weight of shoot (FWS), dry weight of shoot (DWS) and shoot ratio (SR) (Table 1). There was no difference for FWS and DWS among Ferrum sulphuricum dynamizations within the genotypes, but under the dynamization $48 \mathrm{CH}$, Cedro genotype had weight accumulation greater than Santa Clara. For SR, all dynamizations were different and with values lower than those of the control treatments for the two genotypes. Lower shoot ratio is not considered a negative factor, since it can indicate the most returned root system, which is favorable for the healthy growth of the plant (TAIZ; ZIEGER, 2013). 
M. V. TOLEDO et al.

Table 1. Fresh weight of shoot (FWS), dry weight of shoot (DWS) and shoot ratio (SR) of Cedro and Santa Clara tomato genotypes infected with Oidium neolycopersici and treated with the homeopathic medicine Ferrum sulphuricum.

\begin{tabular}{ccccccc}
\hline \multirow{2}{*}{$\begin{array}{c}\text { Dynamization } \\
(\mathrm{CH})\end{array}$} & \multicolumn{2}{c}{ FWS $(\mathrm{g})$} & \multicolumn{2}{c}{ DWS $(\mathrm{g})$} & \multicolumn{2}{c}{ SR $(\%)$} \\
\cline { 2 - 7 } & Cedro & Santa Clara & Cedro & Santa Clara & Cedro & Santa Clara \\
\hline 6 & $137.00 \mathrm{Aa}$ & $123.98 \mathrm{Aa}$ & $28.78 \mathrm{Aa}$ & $26.74 \mathrm{Aa}$ & $92.59 \mathrm{Aa}$ & $92.57 \mathrm{Aa}$ \\
12 & $137.50 \mathrm{Aa}$ & $126.12 \mathrm{Aa}$ & $27.62 \mathrm{Aa}$ & $26.32 \mathrm{Aa}$ & $92.72 \mathrm{Aa}$ & $92.75 \mathrm{Aa}$ \\
24 & $115.72 \mathrm{Aa}$ & $136.22 \mathrm{Aa}$ & $27.96 \mathrm{Aa}$ & $27.36 \mathrm{Aa}$ & $92.48 \mathrm{Aa}$ & $92.50 \mathrm{Aa}$ \\
48 & $151.42 \mathrm{Ab}$ & $119.38 \mathrm{Aa}$ & $30.34 \mathrm{Ab}$ & $25.52 \mathrm{Aa}$ & $91.92 \mathrm{Aa}$ & $92.20 \mathrm{Aa}$ \\
72 & $143.62 \mathrm{Aa}$ & $141.26 \mathrm{Aa}$ & $27.86 \mathrm{Aa}$ & $27.68 \mathrm{Aa}$ & $91.81 \mathrm{Aa}$ & $92.57 \mathrm{Aa}$ \\
96 & $133.62 \mathrm{Aa}$ & $131.66 \mathrm{Aa}$ & $28.36 \mathrm{Aa}$ & $26.52 \mathrm{Aa}$ & $91.82 \mathrm{Aa}$ & $92.18 \mathrm{Aa}$ \\
$\mathrm{H}_{2} \mathrm{O}$ & $132.83 \mathrm{Aa}$ & $121.74 \mathrm{Aa}$ & $28.40 \mathrm{Aa}$ & $26.08 \mathrm{Aa}$ & $94.33 \mathrm{Ba}$ & $94.73 \mathrm{Ba}$ \\
$30 \%$ ethanol & $150.00 \mathrm{Aa}$ & $129.18 \mathrm{Aa}$ & $26.40 \mathrm{Aa}$ & $28.84 \mathrm{Aa}$ & $93.34 \mathrm{Ba}$ & $94.69 \mathrm{Ba}$ \\
\hline $\mathrm{CV}(\%)$ & \multicolumn{7}{c}{74.99} & & & 1.21 \\
\hline
\end{tabular}

*Same letters do not differ statistically by the Scott-Knott test at $5 \%$ probability level. Capital letters in the column (among dynamizations) and lowercase letters in the row (between cultivars).

Regarding the volume of the root (VR) (Table 2), for Cedro genotype, all dynamizations increased the values compared to control treatments, ranging from $50 \%(6,12,24$ and $48 \mathrm{CH})$ to $110 \%$ (72 and $96 \mathrm{CH})$, and for Santa Clara genotype, only 72 and $96 \mathrm{CH}$ were different and greater, $137.14 \%$ and $194.29 \%$, respectively, than $30 \%$ ethanol. A different response among genotypes for the $6 \mathrm{CH}$ dynamization occurred; Cedro showed bigger root volume than Santa Clara. For dry weight of the root (DWR), all dynamizations were better than the control treatments, for both genotypes. In addition, Cedro genotype responded better to Ferrum sulphuricum at $48 \mathrm{CH}$ dynamization compared to Santa Clara.

In the root ratio (RR), all dynamizations were better than the control treatments, but there was no difference between genotypes. Plants with larger root system, higher volume, higher weight and higher proportion of roots relative to the total weight of the plant have better conditions to respond to the production factors. Toledo, Stangarlin, and Bonato (2015) also observed response of tomato plants, infected with Alternaria solani, to Ferrum sulphuricum for VR and DWR when using dynamizations $60 \mathrm{CH}$ and $6 \mathrm{CH}$, and found an increase of $65.1 \%$ in DWR and $16.67 \%$ in VR, respectively.

Marques, Silva, and Bonato (2008) also observed effect of homeopathy on plant development. They used five dynamizations $(3,6$, 12, 24 and 30CH) of citronella (Cymbopogon winterianus Jowitt) to study the growth and germination of Sida rhombifolia L., and found that all treatments stimulated root growth; dynamizations 3 , 6 and $12 \mathrm{CH}$ stimulated shoot growth, but the dynamization $24 \mathrm{CH}$ inhibited it. Dynamizations 6 ,
12 and $30 \mathrm{CH}$ increased the percentage of germinated seeds.

Bonato and Silva (2003) also observed an increase in radish growth with homeopathic medicine Sulphur, which increased the fresh and dry weight, as well as root system, plant length, leaf length and root diameter, indicating that this medicine could be an alternative when used to increase productivity and to improve the appearance of plants.

For variables related to plant reproduction, there were differences in the number of flowers, number of fruits and dry weight of fruits only for tomato genotypes, but not for the Ferrum sulphuricum dynamizations. There was a difference between genotype responses regarding fresh and dry weight of fruits for the first and second bunches (Table 3); Santa Clara was better than Cedro at 6 and $48 \mathrm{CH}$ dynamizations for fresh weight of fruit and at $6 \mathrm{CH}$ for dry weight of fruit in the first bunch. However, for the second bunch, at $6 \mathrm{CH}$, Santa Clara was worse than Cedro for fresh and dry weight of fruits.

Concerning $O$. neolycopersici sporulation, for Cedro, there was no effect of dynamizations on the number of spores per colony, although all the dynamizations led to values lower than those of the control treatments by up to $75 \%(96 \mathrm{CH})$ (Figure 4$)$. For Santa Clara, all dynamizations reduced sporulation, with the exception of $48 \mathrm{CH}$, ranging from $20.44 \%(24 \mathrm{CH})$ to $49.77 \%(72 \mathrm{CH})$. When comparing the genotype responses, Cedro showed fewer spores than Santa Clara at $48 \mathrm{CH}$ dynamization. Data indicated a difference in the response of the genotypes to Ferrum sulphuricum, which also occurred with disease severity (AUDPC) and SPAD chlorophyll index. 
M. V. TOLEDO et al.

Table 2. Volume of root (VR), dry weight of the root (DWR), root ratio (RR) of Cedro and Santa Clara tomato genotypes infected with Oidium neolycopersici and treated with the homeopathic medicine Ferrum sulphuricum.

\begin{tabular}{ccccccc}
\hline \multirow{2}{*}{$\begin{array}{c}\text { Dynamization } \\
(\mathrm{CH})\end{array}$} & \multicolumn{2}{c}{ VR $(\mathrm{mL})$} & \multicolumn{2}{c}{ DWR $(\mathrm{g})$} & & \\
\cline { 2 - 6 } & Cedro & Santa Clara & Cedro & Santa Clara & Cedro & Santa Clara \\
\hline 6 & $15.0 \mathrm{Bb}$ & $9.0 \mathrm{Aa}$ & $2.30 \mathrm{Ba}$ & $2.16 \mathrm{Ba}$ & $7.04 \mathrm{Ba}$ & $7.48 \mathrm{Ba}$ \\
12 & $15.0 \mathrm{Ba}$ & $12.0 \mathrm{Aa}$ & $2.16 \mathrm{Ba}$ & $2.04 \mathrm{Ba}$ & $7.28 \mathrm{Ba}$ & $7.25 \mathrm{Ba}$ \\
24 & $15.0 \mathrm{Ba}$ & $14.0 \mathrm{Aa}$ & $2.27 \mathrm{Ba}$ & $2.23 \mathrm{Ba}$ & $7.52 \mathrm{Ba}$ & $7.50 \mathrm{Ba}$ \\
48 & $15.0 \mathrm{Ba}$ & $12.8 \mathrm{Aa}$ & $2.66 \mathrm{Bb}$ & $2.16 \mathrm{Ba}$ & $8.08 \mathrm{Ba}$ & $7.80 \mathrm{Ba}$ \\
72 & $20.0 \mathrm{Ba}$ & $16.6 \mathrm{Ba}$ & $2.46 \mathrm{Ba}$ & $2.20 \mathrm{Ba}$ & $8.19 \mathrm{Ba}$ & $7.43 \mathrm{Ba}$ \\
96 & $21.0 \mathrm{Ba}$ & $20.6 \mathrm{Ba}$ & $2.53 \mathrm{Ba}$ & $2.25 \mathrm{Ba}$ & $8.18 \mathrm{Ba}$ & $7.82 \mathrm{Ba}$ \\
$\mathrm{H}_{2} \mathrm{O}$ & $8.6 \mathrm{Aa}$ & $9.0 \mathrm{Aa}$ & $1.70 \mathrm{Aa}$ & $1.46 \mathrm{Aa}$ & $5.67 \mathrm{Aa}$ & $5.27 \mathrm{Aa}$ \\
$30 \%$ ethanol & $10.0 \mathrm{Aa}$ & $7.0 \mathrm{Aa}$ & $1.88 \mathrm{Aa}$ & $1.62 \mathrm{Aa}$ & $6.66 \mathrm{Aa}$ & $5.31 \mathrm{Aa}$ \\
\hline $\mathrm{CV}(\%)$ & \multicolumn{3}{c}{15.82} & & 15.68 \\
\hline
\end{tabular}

*Same letters do not differ statistically by the Scott-Knott test at 5\% probability level. Capital letters in the column (among dynamizations) and lowercase in the row (between genotypes). $\left({ }^{*}\right)$ data transformed to $\left.(\mathrm{X}+1.0)^{0.5}\right)$.

Table 3. Fresh weight of fruit for first bunch (FWF1) and second bunch (FWF2), and dry weight of fruit for first bunch (DWF1) and second bunch (DWF2) of Cedro and Santa Clara tomato genotypes infected with Oidium neolycopersici and treated with the homeopathic medicine Ferrum sulphuricum.

\begin{tabular}{|c|c|c|c|c|c|c|c|c|}
\hline \multirow{2}{*}{$\begin{array}{l}\text { Dynamization } \\
(\mathrm{CH})\end{array}$} & \multicolumn{2}{|c|}{ FWF1 (g) } & \multicolumn{2}{|c|}{ DWF1 (g) } & \multicolumn{2}{|c|}{ FWF2 (g) } & \multicolumn{2}{|c|}{ DWF2 (g) } \\
\hline & Cedro & Santa Clara & Cedro & $\begin{array}{l}\text { Santa } \\
\text { Clara }\end{array}$ & Cedro & $\begin{array}{l}\text { Santa } \\
\text { Clara }\end{array}$ & Cedro & $\begin{array}{l}\text { Santa } \\
\text { Clara }\end{array}$ \\
\hline 6 & $21.40 \mathrm{Aa}$ & $49.86 \mathrm{Ab}$ & $1.57 \mathrm{Aa}$ & $3.43 \mathrm{Ab}$ & $10.16 \mathrm{Ab}$ & $0.26 \mathrm{Aa}$ & $0.72 \mathrm{Ab}$ & $0.02 \mathrm{Aa}$ \\
\hline 12 & $28.08 \mathrm{Aa}$ & $37.56 \mathrm{Aa}$ & $2.04 \mathrm{Aa}$ & $2.82 \mathrm{Aa}$ & $4.02 \mathrm{Aa}$ & $6.18 \mathrm{Aa}$ & $0.23 \mathrm{Aa}$ & $0.35 \mathrm{Aa}$ \\
\hline 24 & 36.38Aa & $25.08 \mathrm{Aa}$ & $2.65 \mathrm{Aa}$ & $1.82 \mathrm{Aa}$ & $1.70 \mathrm{Aa}$ & $1.28 \mathrm{Aa}$ & $0.12 \mathrm{Aa}$ & $0.09 \mathrm{Aa}$ \\
\hline 48 & $22.58 \mathrm{Aa}$ & $43.86 \mathrm{Ab}$ & $1.83 \mathrm{Aa}$ & $2.95 \mathrm{Aa}$ & $2.20 \mathrm{Aa}$ & $1.10 \mathrm{Aa}$ & $0.16 \mathrm{Aa}$ & $0.04 \mathrm{Aa}$ \\
\hline 72 & $20.52 \mathrm{Aa}$ & $35.76 \mathrm{Aa}$ & $1.57 \mathrm{Aa}$ & $3.00 \mathrm{Aa}$ & $1.02 \mathrm{Aa}$ & 7.04Aa & $0.14 \mathrm{Aa}$ & $0.10 \mathrm{Aa}$ \\
\hline 96 & $30.18 \mathrm{Aa}$ & $27.88 \mathrm{Aa}$ & $2.36 \mathrm{Aa}$ & $1.90 \mathrm{Aa}$ & $3.10 \mathrm{Aa}$ & $3.18 \mathrm{Aa}$ & $0.24 \mathrm{Aa}$ & $0.23 \mathrm{Aa}$ \\
\hline $\mathrm{H}_{2} \mathrm{O}$ & $24.10 \mathrm{Aa}$ & $33.52 \mathrm{Aa}$ & $1.94 \mathrm{Aa}$ & $3.48 \mathrm{Aa}$ & $3.28 \mathrm{Aa}$ & $0.50 \mathrm{Aa}$ & $0.25 \mathrm{Aa}$ & $0.04 \mathrm{Aa}$ \\
\hline Ethanol & $21.34 \mathrm{Aa}$ & $40.80 \mathrm{Aa}$ & $1.52 \mathrm{Aa}$ & $4.02 \mathrm{Ab}$ & $1.54 \mathrm{Aa}$ & $4.16 \mathrm{Aa}$ & $0.09 \mathrm{Aa}$ & $0.21 \mathrm{Aa}$ \\
\hline $\mathrm{CV}(\%)$ & \multicolumn{2}{|c|}{$26.20 *$} & \multicolumn{2}{|c|}{$17.99 *$} & \multicolumn{2}{|c|}{$62.36^{*}$} & \multicolumn{2}{|c|}{$12.52 *$} \\
\hline
\end{tabular}

*Same letters do not differ statistically by the Scott-Knott test at $5 \%$ probability level. Capital letters in the column (among dynamizations) and lowercase in the row (between genotypes). $(*)$ data transformed to $\left.(\mathrm{X}+1.0)^{0.5}\right)$.

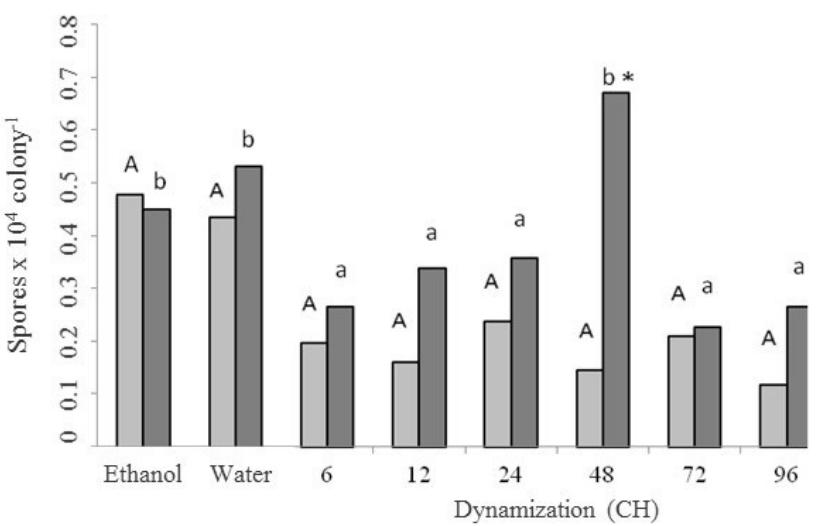

Figure 4. Sporulation of Oidium neolycopersici on Cedro ( $\square$ ) and Santa Clara $(\square)$ tomato genotypes treated with homeopathic medicine Ferrum sulphuricum at dynamizations 6, 12, 24, 48, 72 and 96CH, compared with $30 \%$ ethanol and distilled water. Same letters do not differ statistically by the Scott-Knott test at $5 \%$ probability; capitals letters within Cedro and lowercase letters for Santa Clara (* difference between genotypes). CV (\%): 12.88 (data transformed to $\left.(\mathrm{X}+1.0)^{0.5}\right)$. 
Santa Clara tomato, from the Santa Cruz group, is a hybrid cultivar, of indeterminate growth, oblong in shape, and resistant to Fusarium (strain 2), Verticilium and Stemphylium solani. It was the main planting material in the 1980s and 1990s, but it has no long life characteristics, thus it lost space for other materials that have a longer post-harvest life (ALVARENGA, 2004)

Cedro is a hybrid cultivar, of indeterminate growth, salad type and with great farmers' acceptance, in spite of the high seed cost, high multiviral resistance, easy cultivation and high production potential; it is long life type, a good characteristic for the market. It has resistance to Verticilium, Fusarium strain 2, nematodes, tomato mosaic virus and tospovirus (ISLA, 2020). This work showed that less genetically manipulated or less "improved" materials, such as Santa Clara, respond better to homeopathy; farmers have stated it in their daily practice (data not shown).

These results refer to the genetic erosion concept, which is the loss of genetic diversity of crops. According to several countries around the world, the main cause is the replacement of local varieties by "improved" varieties and species. As more farmers use new commercial varieties, it is possible that the overall number of varieties has been reduced.

The genetic diversity of species is fundamental to maintaining the natural ability to respond to climate change and to all types of biotic and abiotic stresses. However, there is a marked loss of diversity, mainly due to the man's action, replacing local varieties by so-called modern, hybrid and, more recently, transgenic varieties (CARVALHO; SILVA; MEDEIROS, 2009). Homeopathy acts in the self-regulation of the individual; more improved materials have a lower natural capacity to respond to external stimuli, which makes their homeostasis more difficult.

\section{CONCLUSION}

The homeopathic medicine Ferrum sulphuricum at different dynamizations reduces powdery mildew, increases the relative chlorophyll index and the volume and dry weight of root in tomato plants. There is a differential response of tomato genotypes to Ferrum sulphuricum.

\section{REFERENCES}

ALVARENGA, M. A. R. Tomate: produção de campo, em casa de vegetação e hidroponia. 1 . ed. Lavras, MG: UFLA, 2004. 455 p.

ANVISA - Agência Nacional de Vigilância
Sanitária. Farmacopéia homeopática brasileira. 3. ed. Brasília, DF: ANVISA, 2011. 364 p.

BALBI-PEÑA, M. I. B. et al. Controle de Alternaria solani em tomateiro por extratos de Curcuma longa e curcumina - II Avaliação in vivo. Fitopatologia Brasileira, 31: 401-404, 2006.

BONATO, C. M.; SILVA, E. P. Effect of the homeopathic solution Sulphur on the growth and productivity of radish. Acta Scientiarum Agronomy, 25: 259-263, 2003.

BONATO, C. M. et al. Homeopatia simples: alternativa para agricultura familiar. 1. ed. Marechal Cândido Rondon, PR: Líder, 2012. 36 p.

CARNEIRO, S. M. T. P. G.; TEIXEIRA, M. Z. Homeopatia e controle de doenças de plantas e seus patógenos. Scientia Agraria Paranaensis, 17: 250262,2018

CARVALHO, J. M. F. C; SILVA, M. M. A; MEDEIROS, M. J. L. Perda e conservação dos recursos genéticos naturais. Campina Grande, $\mathrm{PB}$ : EMBRAPA, 2009. 20 p. (Documentos, 221).

DOSSA, D; FUCHS, F. Tomate: análise técnicoeconômica e os principais indicadores da produção nos mercados mundial, brasileiro e paranaense. Curitiba, PR: CEASA, 2017. 50 p. (Boletim Técnico, 03).

FERREIRA, D. F. Sisvar: a computer statistical analysis sistem. Ciência e Agrotecnologia. 35: 1039 $-1042,2011$.

HAMERSCHMIDT, I. et al. Manual de olericultura orgânica. Curitiba, PR: EMATER/ SEAB, 2012. 129 p.

INOUE-NAGATA, A. K. et al. Manual de fitopatologia: doenças das plantas cultivadas. $v$. 2., 5. ed. São Paulo, SP: Ceres, 2016. 810 p.

ISLA. Isla sementes. Porto Alegre, 2020. Disponível em: $\quad<$ http://www.isla.com.br/cgi-bin/detalhe.cgi? $\mathrm{id}=278>$. Acesso em: 04 mai. 2020.

MALAVOLTA, E.; VITTI, G. C.; OLIVEIRA, S. A. Avaliação do estado nutricional das plantas. 2. ed. Piracicaba, SP: Potafós, 1997. 319 p.

MARQUES, P. C.; RISSATO, B. B.; SCHWANESTRADA, K. R. F. Crescimento micelial de Sclerotinia sclerotiorum, repertorização de sintomas e controle do mofo branco em tomateiro por medicamentos homeopáticos. In: AMARAL, H. F.; SCHWAN-ESTRADA, K. R. F. (Eds.). Agricultura em bases agroecológicas e conservacionista. Ponta 
Grossa, PR: Atena, 2020. v. 1, cap. 15, p. 160-171.

MARQUES, R. M.; SILVA, G. G. M.; BONATO, C. M. Effects of high dilutions of Cymbopogon winterianus Jowitt (citronella) on the germination and growth of seedlings of Sidar hombifolia. International Journal of High Dilution Research, 7: 31-35, 2008.

MIORANZA, T. M. et al. Control of Meloidogyne incognita in tomato plants with highly diluted solutions of Thuya occidentalis and their effects on plant growth and defense metabolism. Semina, 38: 2187-2200, 2017.

PUSTIGLIONE, M. O moderno organom da arte de curar. 2. ed. São Paulo, SP: Typus, 2004. 320 p.

RISSATO, B. B. et al. Homeopatia como método alternativo no controle de doenças em plantas. Journal of Agronomic Sciences. 5: 92-105, 2016.

SALVUCCI, B. J.; AEGERTER, E. M.; MIYAO, I. First report of powdery mildew caused by Oidium lycopersici in field-grown tomatoes in California. Plant Disease, 100: 1497-1497, 2016.

SATKOVÁ, P. et al. Diverse responses of wild and cultivated tomato to BABA, oligandrin and Oidium neolycopersici infection. Annals of Botany, 119: 829-840, 2017.

SHANER, G.; FINNEY, R. E. The effect of nitrogen fertilization on the expression of slow mildewing resistance in Knox wheat. Phytopathology, 67: 1051 $-1056,1977$.

SOUZA, J. L.; RESENDE, P. Manual de horticultura orgânica. 1. ed. Viçosa, MG: Aprenda Fácil, 2003. 564 p.

TAIZ, L.; ZEIGER, E. Fisiologia vegetal. 5. ed. Porto Alegre, RS: Artmed, 2013. 918 p.

TOLEDO, M. V.; STANGARLIN, J. R.; BONATO, C. M. Controle da pinta preta e efeito sobre variáveis de crescimento em tomateiro por preparados homeopáticos. Summa Phytopathologica, 41: 126$132,2015$.

TOLEDO, M. V. et al. Fungitoxicity activity of homeopathic medicines on Alternaria solani. African Journal of Agricultural Research, 11: 3824-3838, 2016.

YANAR, Y.; YANAR, D.; GEBOLOGLU, N. Control of powdery mildew on tomato by foliar sprays of liquid potassium silicate. African Journal of Biotechnology, 10: 3121-3123, 2011.

This work is licensed under a Creative Commons Attribution-CC-BY https://creativecommons.org/licenses/by/4.0/ 